\title{
ENVIRONMENTAL EXERGY ANALYSIS OF WASTEWATER TREATMENT PLANTS
}

\author{
C. H. Mora. B ${ }^{\text {a }}$, \\ and S. de Oliveira $\mathbf{J r}^{\mathbf{b}}$ \\ Universidade de São Paulo \\ Departamento de Engenharia Mecânica \\ Av. Prof. Mello Moraes n ${ }^{\circ} 2.231$ \\ Cidade Universitária \\ CP. 05508-900, São Paulo, SP, Brasil \\ a carlos.bejarano@poli.usp.br \\ bsilvio.oliveira@poli.usp.br
}

\section{NOMENCLATURE}

$B_{\text {Deact. }} \quad$ exergy of additional natural resources destroyed during waste deactivation $[\mathrm{kW}]$

$B_{\text {Disp. }} \quad$ exergy related to waste disposal of the process [kW]

$B_{\text {Nat.Res }}$ exergy of the natural resources consumed by the processes $[\mathrm{kW}]$

$B O D \quad$ Biochemical Oxygen Demand [mol/L] $B_{\text {Prep. }}$ exergy required for extraction and preparation of the natural resources [kW]

$B_{\text {Product }}$ exergy of the useful effect of a process

[kW]

$B_{\text {Waste }}$ exergy of waste, which includes the exergies of solid wastes, rejected heat, and emissions $[\mathrm{kW}]$

COD Chemical Oxygen Demand [mol/L]

$\eta_{\text {env,exerg }}$ environmental exergy efficiency

$R_{\text {pol,t }} \quad$ total pollution rate

WTP Wastewater Treatment Plants

\section{INTRODUCTION}

There is an increasing demand for more sustainable wastewater treatment systems. However, the criteria needed to characterize such a system are not fully developed. One important tool in the analysis of the sustainability of a wastewater treatment system is the exergy analysis. Hellström (1997) showed how an exergy analysis could be used to estimate the consumption of physical resources at a wastewater treatment plant.

Some authors have suggested that the quantification of the environmental impact of energy conversion processes can be better driven by the use of the exergy concept (Rosen and Dincer (1997); Gong (1999); Wall; Gong (2001)). Others went beyond and calculated that impact based on the exergy (Botero (2000); Creyts; Carey (1997); Gong; Wall (2001); Makarytchev (1997); Rosen; Dincer (1999); Valero; Arauzo (1991)). According to Szargut et al. (1988), exergy is defined as the amount of work obtainable when some matter is brought to a state of thermodynamic equilibrium with the common components of the natural surroundings by means of reversible processes, involving interaction only with those components of nature.

Exergy can be defined as a sustainable development registration that emphasizes the connection between generated services/products and used resources. This fact makes exergy a better measure of the damage and a good ecological index since a high exergy efficiency means less exergy wastes to the environment or less environmental damage (Gong (1999); Gong; Wall (2001)).

Based on this premise, in this work the "exergy efficiency" is proposed as an environmental performance index which includes the aspects of energy efficiency and environmental impact of the energy conversion processes.

The evaluation of the environmental impact of energy conversion processes using the environmental exergy efficiency, $\eta_{\text {env,exerg, }}$ is complemented with the calculation of the total pollution rate $R_{p o l, t}$ (Makarytchev (1997)). 


\section{WASTEWATER TREATMENT PLANTS}

The analysis of environmental impact was applied to two Wastewater Treatment Plants (WTP), located in the Metropolitan Area of São Paulo, that belong to Tietê River Depollution Program.A detailed description of WTPs Barueri and Parque Novo Mundo is presented in Mora (2004). In Fig. 1, it is illustrated the flowchart of WTPs Barueri and Parque Novo Mundo.

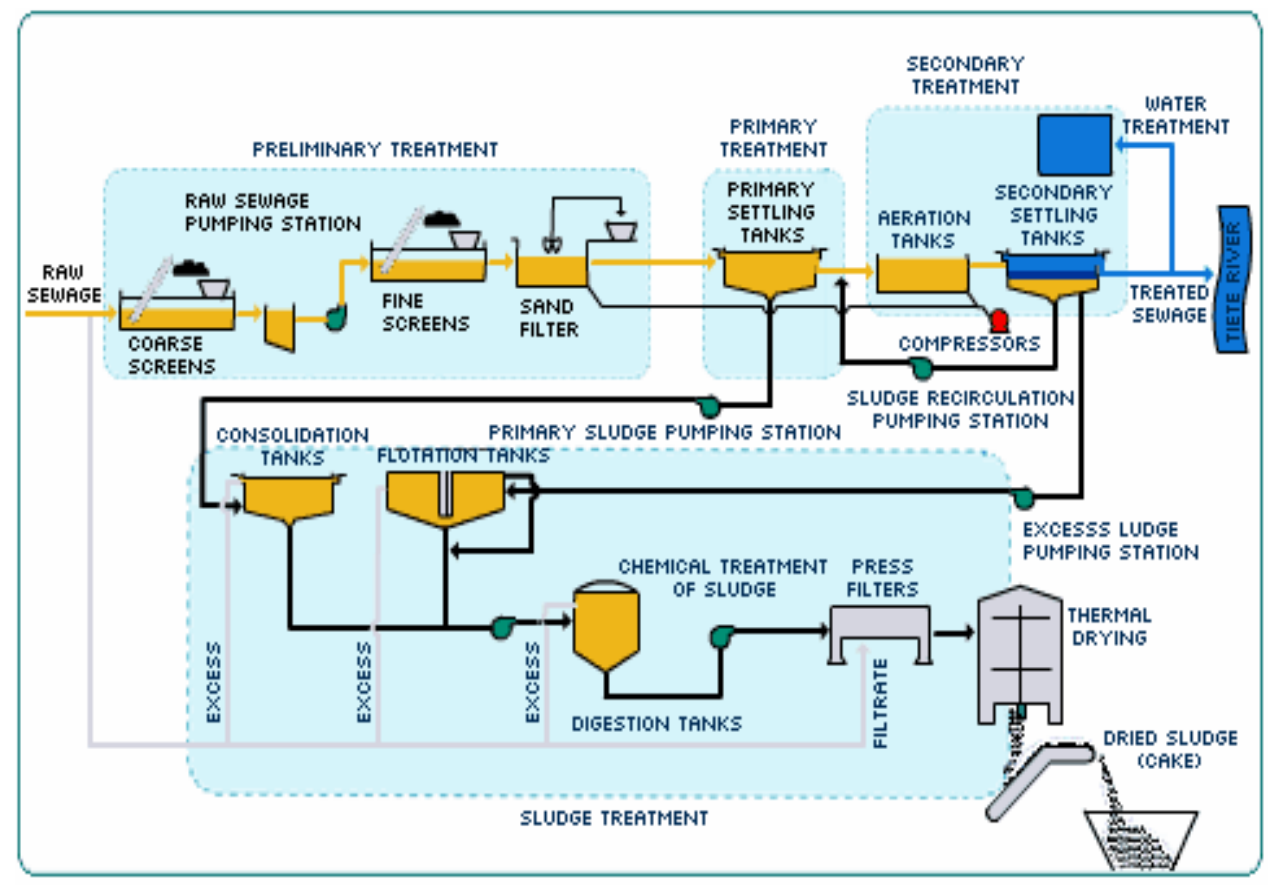

Figure 1. Wastewater Treatment Plant (SABESP (2004)).

The plant type illustrated are conventional and secondary activated sludge treatment with organic material removal of $90 \%$ Biochemical Oxygen Demand (BOD). The treatment process that take place in the plants consist of the following stages: a) The Preliminary Treatment consist of two phases: screening and sand removal. Screening removes large solids, which are retained by the screens. The main reasons for screening are to protect the pumps and tubes, later treatment units and the tanks. In sand removal, the sand is removed by sedimentation. The aims of sand removal are to protect equipment from wear and turbulence, eliminate or reduce the risk of blockages in pipes, tanks, siphons and passages, and simplify the liquid transportation, especially transfer of sludge (see Fig.1).

b) The Primary Treatment consists of primary settling tank which tanks are rectangular or round. Sewage flows slowly through the tanks, allowing suspended solids to gradually settle to the bottom of the tank. This solid mass, called primary sludge, can be consolidated at the bottom of the tank and sent directly for digestion, or can be sent to the consolidation tanks. A large part of these solids is made up of organic matter. Depending on the nature and size of the suspended solids, rotating sieves may be used instead of the screening system or the primary settling tanks (WTP PNM). The aim is to separate the larger suspended solids, by means of flowing them through the moving sieves, from the center to the outside. The retained solids are continuously removed in buckets.

c) The Secondary Treatment is made of three phases. In the aeration tank (phase one), organic matter is removed by biochemical reaction, using microorganisms (bacteria, protozoans, fungi) in the aeration tank. This process relies on contact between the microorganisms and the organic material in the sewage, which forms their food. They convert the organic material into carbon dioxide, water and their own cell structure. The secondary settling tanks perform an important function in the activated sludge process (phase two), being responsible for the separation of the suspended solids present in the aeration tank, allowing a clarified liquid to flow out, leaving sediments solids at the base of the tank, which can be returned in a higher concentration. The effluent from the aeration tanks is settled, so that the activated sludge is separated and returns to the aeration tanks. The return of this sludge is necessary to supply the aeration tanks with a sufficient quantity of microorganisms to keep the feeding process going in sufficient strength to decompose the organic material efficiently. The liquid effluent from the secondary settling tanks is either released directly or conveyed for treatment so that it can be reused 
internally or sold for uses such as washing streets and watering gardens. In the excess sludge pumping station hapes the third stage of the secondary treatment: the sludge formed from the suspended solids by means of the alimentation of microorganisms must be removed to maintain equilibrium in the system (solids in = solids out). The sludge is extracted and sent for treatment (see Fig.1).

d) The Sludge Treatment consists of five phases: i) Consolidation: this stage takes place in consolidation and flotation tanks. As the sludge still contains large quantities of water, its volume must be reduced. The consolidation process increases the solid content in the sludge, reducing its volume. This process can increase the proportion of solids from $1 \%$ to $5 \%$. In this way, subsequent units, such as digester tanks and drying units have less work to do. The most common methods include gravity consolidation and flotation. Gravity consolidation is based on the principle of zone sedimentation, as in the conventional settling tanks. The consolidated sludge is removed from the base of the tank. Flotation involves the introduction of air in a compression chamber. When the solution is depressurized, the dissolved air forms micro bubbles that carry the clumps of sludge to the surface, where they are removed. ii) Anaerobic Digestion: digestion has the following aims: to destroy dangerous microorganisms, to stabilize unstable substances and organic material present in the crude sludge, reduce the volume of the sludge through liquefaction, gasification and consolidation, to enable the sludge to reduce its liquid level, and to allow the use of the sludge - after stabilization - as a fertilizer or soil conditioner. Without oxygen, only anaerobic bacteria survive, which are able to use combined oxygen. Acidogenic bacteria break down carbohydrates, proteins and lipids, turning them into volatile acids. Methanogenic bacteria convert a large part of these acids into gases, principally methane. The stabilization of these substances can also be performed by addition of chemicals, a process known as chemical stabilization. iii) Chemical Conditioning: chemical conditioning results in the coagulation of solids and the freeing of absorbed water. Conditioning is used before the mechanical drying systems, such as filtration, centrifuging, etc. The chemicals used include iron chloride, line, aluminum sulfate and organic polymers. iv) Press Filters: drying in the press filters occurs under high pressure. The advantages of this system include: high concentration of solids in the sludge cake, low turbidity in the filtrate and high solid retention. The resulting proportion of solids is between $30 \%$ and $40 \%$ for a 2 to 5 hour filtration cycle - the time needed to fill the press, maintain it under pressure, open it, remove the cake and close the press. v) Thermal Drying: thermal drying of the sludge is the process of reduction through evaporation of water into the atmosphere by means of heat, resulting in a proportion of solids between $90 \%$ and $95 \%$. This reduces the final volume of the sludge significantly SABESP (2004).

Tables 1, 2, 3 and 4 present the composition of the raw and treated sewage as well as the sludge composition of Barueri and Parque Novo Mundo Wastewater Treatment Plants.

Table 1. Composition of the raw and treated sewage for Barueri Wastewater Treatment Plant.

\begin{tabular}{|l|c|c|}
\cline { 2 - 3 } \multicolumn{1}{c|}{} & \multicolumn{2}{c|}{ Composition (mol/L) } \\
\cline { 2 - 3 } \multicolumn{1}{c|}{} & $\begin{array}{c}\text { Raw } \\
\text { sewage }\end{array}$ & $\begin{array}{c}\text { Treated } \\
\text { sewage }\end{array}$ \\
\hline$B O D$ & 0.00756 & 0.00048 \\
\hline$C O D$ & 0.01219 & 0.00143 \\
\hline $\mathrm{NH}_{3}$ & 0.00155 & 0.00021 \\
\hline $\mathrm{NO}_{3}$ & $1.6 \mathrm{E}-06$ & $1.7 \mathrm{E}-06$ \\
\hline $\mathrm{NO}_{2}$ & $1.1 \mathrm{E}-07$ & $2.3 \mathrm{E}-06$ \\
\hline $\mathrm{S}_{2}$ & $1.6 \mathrm{E}-05$ & $1.6 \mathrm{E}-05$ \\
\hline $\mathrm{SO}$ & 0.00043 & 0.00027 \\
\hline $\mathrm{Cd}$ & $5.3 \mathrm{E}-08$ & $5.3 \mathrm{E}-08$ \\
\hline $\mathrm{Ni}$ & $6.3 \mathrm{E}-07$ & $6.6 \mathrm{E}-07$ \\
\hline $\mathrm{Ag}$ & $1.0 \mathrm{E}-07$ & $3.7 \mathrm{E}-08$ \\
\hline $\mathrm{Zn}$ & $3.6 \mathrm{E}-06$ & $1.4 \mathrm{E}-06$ \\
\hline $\mathrm{Mg}$ & $1.7 \mathrm{E}-06$ & $1.2 \mathrm{E}-06$ \\
\hline $\mathrm{Mo}$ & $2.1 \mathrm{E}-07$ & $2.1 \mathrm{E}-07$ \\
\hline $\mathrm{Pb}$ & $1.7 \mathrm{E}-07$ & $1.4 \mathrm{E}-07$ \\
\hline $\mathrm{Cu}$ & $8.7 \mathrm{E}-07$ & $4.1 \mathrm{E}-07$ \\
\hline $\mathrm{Cr}$ & $1.6 \mathrm{E}-06$ & $5.7 \mathrm{E}-07$ \\
\hline $\mathrm{Fe}$ & $5.4 \mathrm{E}-05$ & $8.6 \mathrm{E}-06$ \\
\hline $\mathrm{Alcohol}$ & $3.4 \mathrm{E}-06$ & $5.1 \mathrm{E}-07$ \\
\hline $\mathrm{P}$ & 0.00012 & $5.8 \mathrm{E}-05$ \\
\hline $\mathrm{Detergent}$ & 0.00042 & $3.7 \mathrm{E}-05$ \\
\hline $\mathrm{Sn}$ & $1.1 \mathrm{E}-06$ & $1.1 \mathrm{E}-06$ \\
\hline Overall & $\mathbf{0 . 0 2 2 3 6}$ & $\mathbf{0 . 0 0 2 5 2}$ \\
\hline
\end{tabular}

Table 2. Sludge composition of Barueri Wastewater Treatment Plant.

\begin{tabular}{|l|c|}
\hline Components & Composition (mol/kg) \\
\hline $\mathrm{Cd}$ & 0.00011 \\
\hline $\mathrm{Pb}$ & 0.00079 \\
\hline $\mathrm{Cu}$ & 0.00871 \\
\hline $\mathrm{Cr}$ & 0.00899 \\
\hline $\mathrm{Mg}$ & 0.00443 \\
\hline $\mathrm{Fe}$ & 0.58161 \\
\hline $\mathrm{Ni}$ & 0.00480 \\
\hline $\mathrm{Zn}$ & 0.03183 \\
\hline $\mathrm{Ag}$ & 0.00059 \\
\hline $\mathrm{Mo}$ & 0.00016 \\
\hline Overall & $\mathbf{0 . 6 4 2 0 3}$ \\
\hline
\end{tabular}




\section{ENVIRONMENTAL EXERGY ANALYSIS OF WASTEWATER TREATMENT PLANTS}

\section{Environmental impact exergy based indexes}

The environmental impact of the waste water treatment plants was done by means of evaluating the values of two environmental impact exergy based indexes: the environmental exergy efficiency ( $\left.\eta_{\text {env,exerg }}\right)$ and the total pollution rate $\left(R_{\text {pol, } t}\right)$, as proposed by Makarytchev (1997) and Mora and Oliveira Jr. (2004). The environmental exergy efficiency is defined as the ratio of the final product exergy (or useful effect of a process) to the total exergy of natural and human resources consumed, including all the exergy inputs. That ratio is also an indication of the theoretical potential of future improvements for a process. The environmental exergy efficiency is calculated according to Eq. (1).

$$
\eta_{\text {env,exerg }}=\frac{B_{\text {Product }}}{B_{\text {Nat,Res }}+B_{\text {Prep }}+B_{\text {Deact }}+B_{\text {Disp }}}
$$

Table 3. Composition of the raw and treated sewage for Parque Novo Mundo Wastewater Treatment Plant.

\begin{tabular}{|l|c|c|}
\cline { 2 - 3 } \multicolumn{1}{c|}{} & \multicolumn{2}{c|}{ Composition (mol/L) } \\
\cline { 2 - 3 } \multicolumn{1}{c|}{} & Raw sewage & $\begin{array}{c}\text { Treated } \\
\text { sewage }\end{array}$ \\
\hline BOD & 0.00360 & 0.000734 \\
\hline $\mathrm{NH}_{3}$ & 0.00909 & 0.001359 \\
\hline $\mathrm{NO}_{3}$ & 0.00077 & 0.000357 \\
\hline $\mathrm{NO}_{2}$ & $9.2 \mathrm{E}-06$ & $5.93 \mathrm{E}-05$ \\
\hline $\mathrm{S}_{2}$ & $1.0 \mathrm{E}-06$ & $7.98 \mathrm{E}-06$ \\
\hline $\mathrm{SO}$ & $1.7 \mathrm{E}-05$ & $8.73 \mathrm{E}-06$ \\
\hline $\mathrm{Cd}$ & 0.00049 & 0.000460 \\
\hline $\mathrm{Hg}$ & $7.1 \mathrm{E}-08$ & $7.12 \mathrm{E}-08$ \\
\hline $\mathrm{Ni}$ & $2.7 \mathrm{E}-08$ & $1.36 \mathrm{E}-08$ \\
\hline $\mathrm{Ag}$ & $2.3 \mathrm{E}-06$ & $2.54 \mathrm{E}-06$ \\
\hline $\mathrm{Zn}$ & $1.7 \mathrm{E}-07$ & $1.67 \mathrm{E}-07$ \\
\hline $\mathrm{Mg}$ & $3.7 \mathrm{E}-06$ & $1.84 \mathrm{E}-06$ \\
\hline $\mathrm{Se}$ & $2.2 \mathrm{E}-06$ & $1.82 \mathrm{E}-06$ \\
\hline $\mathrm{Pb}$ & $8.5 \mathrm{E}-09$ & $6.33 \mathrm{E}-09$ \\
\hline $\mathrm{Cu}$ & $3.9 \mathrm{E}-07$ & $3.86 \mathrm{E}-07$ \\
\hline $\mathrm{Cr}$ & $1.7 \mathrm{E}-06$ & $4.72 \mathrm{E}-07$ \\
\hline $\mathrm{Fe}$ & $1,8 \mathrm{E}-06$ & $1.46 \mathrm{E}-06$ \\
\hline $\mathrm{Alcohol}$ & $3.9 \mathrm{E}-05$ & $8.85 \mathrm{E}-06$ \\
\hline $\mathrm{P}$ & $1.8 \mathrm{E}-06$ & $1.29 \mathrm{E}-06$ \\
\hline $\mathrm{Detergent}$ & 0.00010 & $4.11 \mathrm{E}-05$ \\
\hline $\mathrm{Sn}$ & 0.00012 & $3.73 \mathrm{E}-06$ \\
\hline Overall & $4.0 \mathrm{E}-06$ & $4.00 \mathrm{E}-06$ \\
\hline & $\mathbf{0 . 0 1 4 2 8}$ & $\mathbf{0 . 0 0 3 0 5 5 3}$ \\
\hline
\end{tabular}

The total pollution rate is defined as the ratio of the destroyed exergy associated to the process wastes to the exergy of the useful effect of the process. It is determined according to Eq. (2).

Table 4. Sludge composition of Parque Novo Mundo Wastewater Treatment Plant.

\begin{tabular}{|l|c|}
\hline Components & Composition (mol/kg) \\
\hline $\mathrm{Cd}$ & $6.1 \mathrm{E}-05$ \\
\hline $\mathrm{Pb}$ & $4.0 \mathrm{E}-04$ \\
\hline $\mathrm{Cu}$ & $4.4 \mathrm{E}-03$ \\
\hline $\mathrm{Cr}$ & $4.4 \mathrm{E}-03$ \\
\hline $\mathrm{Mg}$ & $4.8 \mathrm{E}-03$ \\
\hline $\mathrm{Fé}$ & $8.4 \mathrm{E}-01$ \\
\hline $\mathrm{Ni}$ & $1.5 \mathrm{E}-03$ \\
\hline $\mathrm{Zn}$ & $1.2 \mathrm{E}-02$ \\
\hline $\mathrm{Ag}$ & $9.5 \mathrm{E}-05$ \\
\hline $\mathrm{Mo}$ & $1.5 \mathrm{E}-04$ \\
\hline $\mathrm{As}$ & $1.4 \mathrm{E}-04$ \\
\hline $\mathrm{Co}$ & $1.1 \mathrm{E}-04$ \\
\hline $\mathrm{Hg}$ & $4.8 \mathrm{E}-09$ \\
\hline $\mathrm{Se}$ & $6.8 \mathrm{E}-09$ \\
\hline Overall & $\mathbf{0 . 8 6 5 8 8}$ \\
\hline \multicolumn{2}{|c|}{} \\
\hline$R_{\text {pol,t }}=\frac{B_{\text {Waste }}}{B_{\text {Deact }}}$ \\
\hline$B_{\text {Product }}$ \\
\hline
\end{tabular}

\section{Exergy evaluation of the environmental impact of the WTP}

The analysis of the environmental impact was realized for the Wastewater Treatment Plants Barueri and Parque Novo Mundo (PNM). Based on the data supplied by SABESP (São Paulo Wastewater Treatment Co.), an exergy analysis of the two WTP was realized considering operation in steady state conditions. The chemical exergies of the substances were determined according to data presented by Szargut et al. (1988).

A detailed description of exergy calculations of WTPs Barueri and Parque Novo Mundo are showed in Mora (2004). With the information generated by this exergy analysis, the environmental exergy efficiency and the total pollution rate were determined and compared.

In Fig. 2 and Fig. 3, are presented the exergy balances for the two Wastewater Treatment Plants 


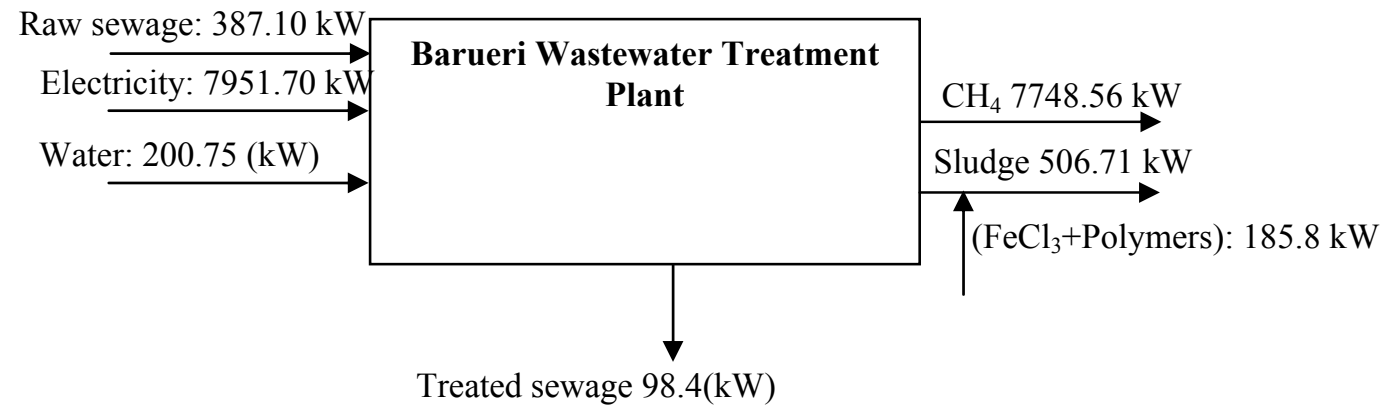

Figure 2. Exergy balance of the Parque Novo Mundo Wastewater Treatment Plant

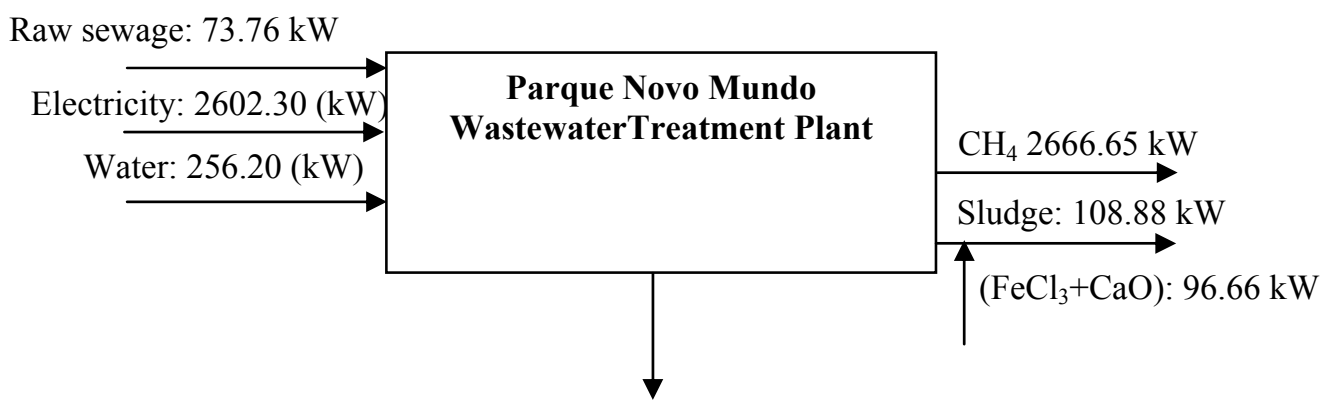

Treated sewage: $60.1 \mathrm{~kW}$

Figure 3. Exergy balance of the Barueri Wastewater Treatment Plant.

In Table 5 are presented the values of the input, output, destroyed and lost exergy flows for Parque Novo Mundo and Barueri. Wastewater Treatment Plants.

In Table 6 are presented the values of the calculated exergy indexes based on the results of the exergy balances. These indexes were used in the evaluation of the environmental impact of the two Wastewater Treatment Plants.

Another important term in the calculation of the exergy indexes is the exergy associated to the wastes of the processes (produced gas and dehydrated mud). If all this exergy was associated to an useful exergetic effect, the values of the $\eta_{\text {env,exerg }}$ for WTP Barueri and PNM would increase significantly. These values are presented in Table 7 .

Table 5. Values of the input, output, destroyed and lost exergy flows for Parque Novo Mundo and Barueri Wastewater Treatment Plants.

\begin{tabular}{|l|c|c|c|}
\hline & \multicolumn{3}{|c|}{ Exergy } \\
\hline Process & $\begin{array}{c}\text { Input } \\
(\mathbf{k W})\end{array}$ & $\begin{array}{c}\text { Output } \\
(\mathbf{k W})\end{array}$ & $\begin{array}{c}\text { Destroyed } \\
\text { and lost } \\
\text { (kW) }\end{array}$ \\
\hline $\begin{array}{l}\text { Parque Novo } \\
\text { Mundo WTP }\end{array}$ & 2932.3 & 60.1 & 2872.2 \\
\hline Barueri WTP & 8539.5 & 98.4 & 8441.1 \\
\hline
\end{tabular}

Table 6. Values of the environmental exergy efficiency and total pollution rate for the analysed Wastewater Treatment Plants.

\begin{tabular}{|l|c|c|}
\hline & \multicolumn{2}{|c|}{ Environmental index } \\
\hline Process & $\eta_{\text {env,exerg }}$ & $\boldsymbol{R}_{\text {pol, } \boldsymbol{t}}$ \\
\hline Parque Novo Mundo WTP & 0.02 & 47.8 \\
\hline Barueri WTP & 0.01 & 85.8 \\
\hline
\end{tabular}

Table 7. Environmental exergy efficiency and total pollution rate for Parque Novo Mundo and Barueri Wastewater Treatment Plants considering the use of the produced gas and dehydrated mud.

\begin{tabular}{|l|c|c|}
\hline & \multicolumn{2}{|c|}{ Environmental index } \\
\hline Process & $\eta_{\text {env,exerg }}$ & $\boldsymbol{R}_{\text {pol, } \boldsymbol{t}}$ \\
\hline Parque Novo Mundo WTP & 0.97 & 0.00 \\
\hline Barueri WTP & 0.98 & 0.00 \\
\hline
\end{tabular}

\section{CONCLUSIONS AND RECOMMENDATIONS}

The present work proposes a scientific methodology based on an exergy criterium to evaluate and quantify the environmental impact of energy conversion processes that take part in waste water treatment plants In this way, it is possible to compare and characterize the environmental exergy performance, and the destruction of the exergy of these processes in the environment.

An overall comparison of the results obtained through the calculation of the indexes of environmental impact $\left(\eta_{\text {env,exerg }}, \boldsymbol{R}_{\text {pol, }, t}\right)$, (see Table 6 and 7), shows that the process that causes the smallest impact in the environment (not considering the cases 
where the methane and the mud of WTPs are useful effects) is the Parque Novo Mundo, Wastewater Treatment Plant since it presents the largest $\eta_{\text {env,exerg }}$ (0.02) and the smallest $\boldsymbol{R}_{\text {pol,t }}$ (47.8). In this comparison it is also observed that in agreement with the $\eta_{\text {env,exerg }}$ values, $(0.01)$, and $\boldsymbol{R}_{\text {pol,t }}$ (85.8), the process that causes the largest impact in the environment is the Wastewater Treatment Plant Barueri, if the by-products (methane and mud) are not considered as useful effect.

The low values of the environmental exergy efficiency $\left(\eta_{\text {env,exerg }}\right)$ for two WTP, are due mainly to the high consumption of electricity for the small generated product, besides the great amount of methane and mud wasted. The electric power consumption represents the largest percentage of the input exergy in the WTP.

Another important fact to be considered in the low values obtained in the environmental exergy efficiency of WTPs, is that the exergy contained in the by-products generated (methane and the mud) is not being used at the moment. If that exergy was considered as a part of the useful effect of the processes of WTP, the values of the $\eta_{\text {env,exerg }}$ for WTP Barueri and PNM would be 0.98 and 0.97 , and the values of the pollution rate $\left(\boldsymbol{R}_{p o l, t}\right)$ would be zero. From the analysis of these last results, it is observed the great potential improvement that these processes would have, by using the mud for agricultural purposes and the methane as a fuel.

Finally, it was concluded that the exergy analyses of the environmental impacts supply a coherent approach with the technological options that excel for the sustainability of environmental solutions, allowing an efficient environmental performance evaluation.

From the analysis of the obtained exergetic indexes, it can be observed that in spite of the limitations of the exergy concept with respect to the toxicity and the biological quality of any substance, it is an useful tool in the quantification of the environmental impact of the energy conversion processes, from the point of view of the processes environmental performance $\left(\eta_{\text {env,exerg }}\right)$, as well as in the characterization of the required exergy to deactivate the process wastes $\left(\boldsymbol{R}_{p o l, t}\right)$.With the obtained results of this evaluation and quantification, it can be made the optimization of the environmental performance of the process, what is reflected directly in its economical analysis.

To complement this work, it is proposed to include a thermoeconomic analysis in the methodology presented for the environmental evaluation of energy conversion processes that take place in wastewater treatment plants.

\section{ACKNOWLEDGEMENT}

The authors acknowledge CNPq for the financial support that allowed the accomplishment of this work.

\section{REFERENCES}

Botero, E. A., 2000, Valoración Exergética de Recursos Naturales, Minerales, Agua y Combustibles Fósiles, Tese Doutorado, Departamento de Ingeniería Mecánica,Universidad de Zaragoza, Zaragoza.

Companhia de Saneamento Básico do Estado de São Paulo, 2004, "Seawage treatment" http://www.sabesp.com.br/english/o_que_fazemos/co leta e tratamento/tratamento de esgotos/default.htm .Creyts, J. C., and Carey, V. P., 1997, Use of Extended Exergy Analysis as a Tool for Assessment of the Environmental Impact of Industrial Processes, Advanced Energy Systems Division, Vol. 37, pp. 129-137.

Gong, M., 1999, On Exergy as an Ecological Indicator. Master of Science Thesis, Department of Physical Resource Theory, Chalmers University of Technology and Göteborg University, Göteborg, Suécia.

Gong, M., Wall, G., 2001, On Exergy and Sustainable Development-part 2: Indicators and Methods, Exergy, Vol. 1, pp. 217-233.

Hellström, D., 1997, An Exergy Analysis for a Wastewater Treatment Plant : an estimation of the consumption of physical resources, Water Environment Research, Vol. 69, pp. 44-51.

Makarytchev, S. V., 1997, Environmental Impact Analysis of ACFB-Based Gas and Power Cogeneration, Energy, Vol. 23, No. 9, pp. 711-717.

Mora, B. C. H., 2004, Exergy Indexes as Indicators of the Environmental Impact of Energy Conversion Processes (in Portuguese), Master dissertation, Polytechnic School of the University of São Paulo, São Paulo, Brazil.

Mora, B. C. H., and Oliveira, Jr. S., 2004, Exergy Efficiency as a Measure of the Environmental Impact of Energy Conversion Processes, in: $17^{\text {th }}$ International Conference on Efficiency, Costs, Optimization and Environmental Impact of Energy Systems- ECOS 2004, Guanajuato, Mexico, pp. 423431. ISBN-968-489-027-3

Rosen, M. A., and Dincer, I., 1997, On Exergy and Environmental Impact, International Journal of Energy Research, Vol. 21, No. 7, pp. 643-654.

Rosen, M. A., and Dincer, I., 1999, Exergy Analysis of Waste Emissions, International Journal of Energy Research, Vol. 23, No. 3, pp. 153-1163.

Szargut, J., Morris, D. R., and Steward, F. R., 1988, Exergy Analysis of Thermal, Chemical, and Metallurgical Processes, New York: Hemisphere.

Valero, A., and Arauzo, I., 1991, Consecuencias Exergeticas Asociadas al Efecto Invernadero, Departamento de Ingeniería Mecánica, Universidad de Zaragoza. Zaragoza. See also: http://www.circe.cps.unizar.es/pub/publicir.nsf.

Wall, G., and Gong, M., 2001, On Exergy and Sustainable Development-part 1: Conditions and Concepts, Exergy,Vol. 1, pp. 128-145.

Received: March 04, 2006

Revised: April 04, 2006

Accepted: May 04, 2006 